\title{
Influence of Motivation to Result of Cognitive Learning in Intergrated Natural Sciences Model Team Games Tournament (TGT) Assistance by Yugioh Card
}

\author{
Reda Harwinanda \\ Universitas Negeri Semarang, Semarang \\ Email: harwinandareda@gmail.com
}

\begin{abstract}
The purpose of this study was to examine the effect of motivation on the result of cognitive learning of the model TGT assisted YuGiOh Card. The population in this study were students of class VII semester 1 with the number of 16 students at MTs Baitul Amin Bali. The type of research design used was a pre-experimental design with a one-shot case study. The study used 2 (two) variables examined in this study, namely motivation and result cognitive learning. The method used in data collection in this research is a questionnaire (questionnaire), documentation and test. The collected data were analyzed using simple linear regression. Based on the motivation data obtained using the model TGT assisted by the YuGiOh card in this study, it shows that students who are in the very good motivation category are $62.5 \%$ and good categories are $37.5 \%$. Data on students' results cognitive learning from post-test results can be categorized very well by $6 \%$, both by $31 \%$, enough by $44 \%$ and less by $19 \%$. The influence of motivation on result cognitive learning using the model TGT assisted YuGiOh card is $27.2 \%$ while the remaining $72.8 \%$ is influenced by learning readiness, social support, and learning facilities. The results showed that learning motivation had a positive effect on result cognitive learning in science learning using the model TGT assisted by YuGiOhcard.
\end{abstract}

Keywords: Model Team Games Tournament (TGT), YuGiOh, Motivation Learning, Cognitive Learning

\section{INTRODUCTION}

Regulation of the Minister of National Education, Permendiknas No. 41 (2007) about the learning process in each elementary and secondary education unit must be interactive, inspirational, fun, challenging, and can motivate students in learning. Each educational unit, the teacher not only makes a variety of creative learning variations but also has to make the students motivated to the material being taught. Sudarmin (2015) explained that integrated natural sciences is a way to observe a phenomenon by looking analytically, rationally correct knowledge, free of superstition and involving students in learning. Science learning at the junior high school level is very important in providing learning experiences through formulating problems, submitting and testing hypotheses, collecting data, processing, interpreting and communicating learning result orally and in writing (Hutauruk \& Simbolon, 2018).

The science lesson in MTs Baitul Amin Bali teacher still uses classical learning method 
that is lecture with teacher centered learning Learning to use the lecture method makes students feel uncontrollably like chatting with a friend and playing while the teacher explains. Motivation is an important part in determining student success in learning (Rifa'i \& Ani, 2012). Motivation is needed in showed the learning process, absorbing, remembering, and influencing result learning that have been taught. Motivation that students have in the learning process is very important role in certain subjects (Sadirman, 2006). Highly motivated students achieve high result learning. Conversely students who have low motivation then low result learning. As added by Putri (2015) showed that there is a significant relationship between interest and motivation to learn on result learning.

The results of cognitive learning in teaching and learning process is very difficult in achieving based on low motivated class. The science lesson in MTs Baitul Amin Bali class 7 has a minimum score of Minimum Criterion (KKM) of 72. However, on the problem that there is an average score of 69 student result learning is still relatively low. At the time of interview with science teachers and grade 8 students the difficult material to understand is the material classification of living things and things. Difficult to understand because of the amount of material that must be taught, the media that have not existed in support of learning, building infrastructure that has not been met and students are less motivated in teaching and learning activities.

One way to influence learning motivation requires an appropriate learning model. The use of cooperative model of Team Games Tournament (TGT) is a solution in making learning innovation to create a pleasant learning atmosphere and involving students in learning (Hakim \& Syofyan, 2017). The learning atmosphere in the TGT model is very influential on learning motivation (Hakim \& Syofyan, 2017). Hakim \& Syofyan (2017) suggests that the TGT type cooperative model is appropriate when using a class with a small number of students. The number of students a little easier in involving students in the process of seeking knowledge. The result of observationat 7th gradein MTs Baitul Amin
Bali is the least class compared with 8 th grade and 9th grade with 16 students. The use of TGT model with a few students will be easier in influencing the motivation to learn and create an up lifting atmosphere.

Teachers also need the media to convey messages in the learning process and to enliven the learning atmosphere. The use of learning media can also create an active learning atmosphere, innovative, creative, effective and exciting (Surahmadi, 2016). Learning media is an intermediary used to convey messages and stimulate the process of teaching and learning activities. Interesting learning media can affect student motivation so it can help students in reminding result learning. Angreni \& Sari (2017) explained that science learning in junior high school should be supported by using media. Learning model combined with media usage can influence student learning motivation along with better result cognitive learning. The research conducted by Wijayanto \& Istianah (2017) showed that the use of game media can influence students learning motivation by $79,72 \%$ with high motivation category, especially in transition stage from adolescent to adult like junior high school student who more likely to need game media to create atmosphere fun in influencing the attention and motivation of learning. Umar, Parmin, \& Wusqo (2016) stated that interest in learning can be seen from the process or not. Fatimah (2017) explained that learning designed using card media can be used as a messenger that can influence and help students. High motivation will make learning comfort enjoyable in the desired result learning.

One of the good learning media to influence motivation and result cognitive learning in teaching and learning process is YuGiOh card game as developed by Roisa \& Liana (2014). Roisa \& Liana explained that the YuGiOh card game is one of the animated card game from Japan. In early 2000 YuGiOh card game spread in European countries and Indonesia among children, adolescents and adults. Supported by Fadilatullailiyah (2015) research by using survey and interview about game branch, YuGiOh card got the highest response among children until adult. 


\section{METHOD}

This research is Pre-Experimental Design. The design used is One-Shot Case Study Design.

Picture 1.One-Shot Case Study

\begin{tabular}{l}
\hline $\mathrm{X} \quad \mathrm{O}_{1}$ \\
Information: \\
$\mathrm{X}=$ motivation \\
$\mathrm{O} 1$ = Value of learning result test
\end{tabular}

The research population is all students of grade VII MTs Baitul Amin Bali academic year $2017 / 2018$. The sample is determined by random sampling technique. The number of samples used is one class that is homogeneous. Homogeneity and normality tests of preliminary data use the value of repetitive material before the classification of living things and objects. the class consists of 17 students. Class VII as an experimental class using YuGiOh-assisted TGT learning model.

The independent variable in this study is the influence of motivation by using the YuGiOh-assisted TGT model. The dependent variable in this study is the result cognitive learning the research activities carried out consist of giving post test and motivation questionnaire.

Methods of data retrieval used in this study are test methods, questionnaires and documentation. The research instrument used there are two, namely test and non test. The test question used to measure cognitive learning is a multiple-choice question based on Bloom's taxonomy. Tests that have been prepared measured the validity, reliability, differentiation, and difficulty level before being used for posttest on research conducted. Non test instruments include a questionnaire. The questionnaire was used to determine the students' motivation toward the application of TGT model with YuGiOh card on the theme of the classification of living creatures and objects.

Posttest data while student responses were analyzed through questionnaire data conducted at the end of learning. Results of cognitive learning and questionnaire were analyzed using simple linear regression.

\section{RESEARCH RESULT AND DISCUSSION}

\section{Research Result}

Motivation learning data is obtained when using the model TGT assitance by YuGiOh card. The distribution of student motivation is presented in Figure 4.1.

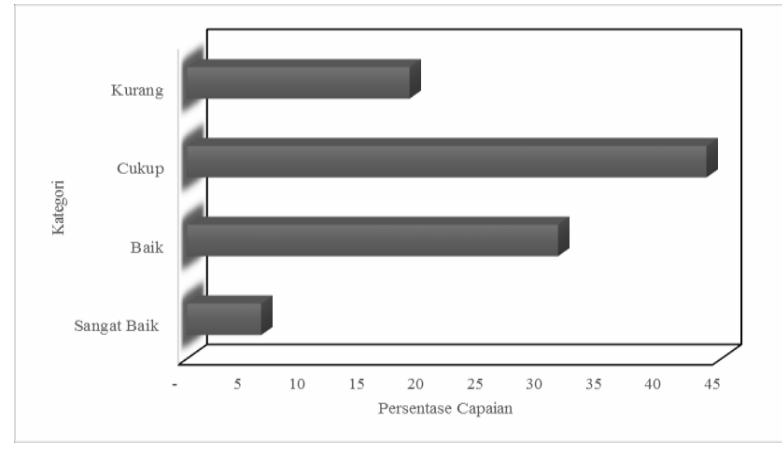

Figure 4.1 Categories of Motivation Learning Figure 4.1 describes the results of the motivation learning category which is very good in the category of $62.5 \%$ and is in the good category of $37.5 \%$. Student learning motivation is assessed from several indicators. The achievement of each indicator of student motivation learning can be seen in Figure 4.2.

Figure 4.2 Achievement of

Motivation Indicators (\%)

Data on result of cognitive learning were obtained when using the TGT model assisted by the YuGiOh card. Data distribution of students' result of cognitive learning is presented in Figure 4.3.

Analysis of data conducted among them the normality test of posttest data. Analysis of result cognitive learning using

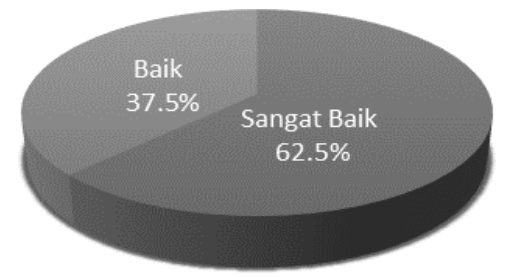

Ttable of 2.14.Also on the Sig column. learning motivation of 0.038 which means there is influence of learning motivation to learning result because less than 0,05 which is interpreted $\mathrm{H} 0$ rejected that there is influence of learning motivation to cognitive learning result through model of TGT assisted card YuGiOh.

Figure 4.3 Achievement of result of cognitive learning $(\%)$ 
Minimum achievement of students' success in working on post-test learning outcomes in meeting the KKM (Minimum Completeness Criteria) limit that has been set by the school is 72 . The achievements obtained during the research using the TGT model assisted by the $\mathrm{YuGiOh}$ card are presented in Figure4.4.

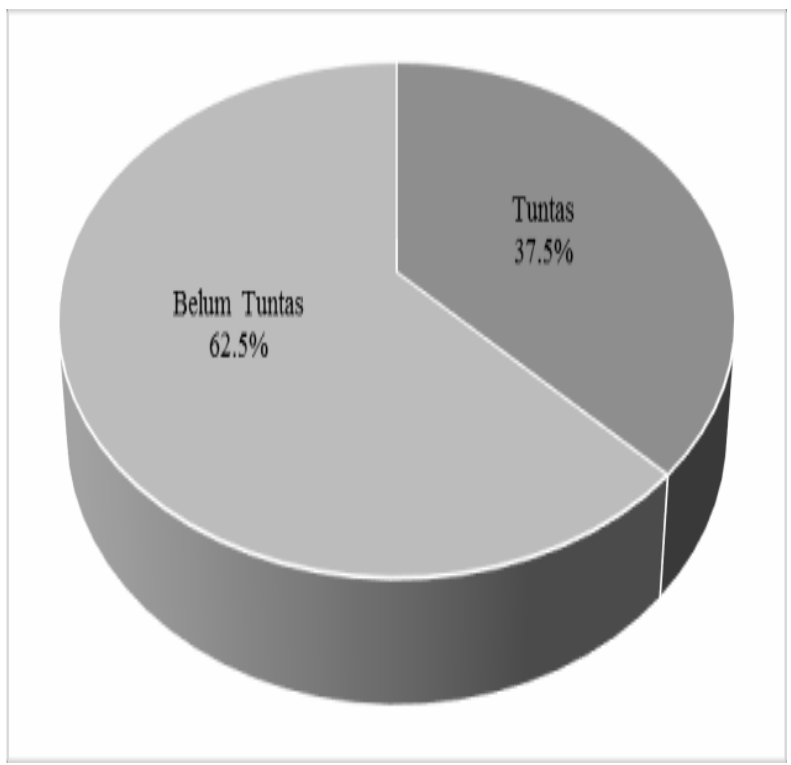

Figure 4.4 Achievement of Student KKM Completeness

Table 4.2 with the result $\mathrm{R}$ Square worth 0.272 can be interpreted there is a large contribution of motivation learning to result cognitive learning of $27.2 \%$.

Table 4.2 Model Summary

\begin{tabular}{llll}
$\mathrm{R}$ & $\begin{array}{l}\mathrm{R} \\
\text { Square }\end{array}$ & $\begin{array}{l}\text { Adjusted } \mathrm{R} \\
\text { Square }\end{array}$ & $\begin{array}{l}\text { Std. Error } \\
\text { of } \\
\text { the Estimate }\end{array}$ \\
$.521^{\mathrm{a}} .272$ & .220 & $\frac{13.07488}{13.0748}$ \\
\hline
\end{tabular}

a. Predictors: (Constant), Motivation to learn (x)

b. Dependent Variable: Result Cognitive learning(y)

Table 4.4 on the regression equation $y$ (dependent) in the column constant with as a equal to $-12,574$. In the learning motivation section $\mathrm{B}$ can be used as $b$ on the regression equation with $b$ value of 0.895 . So we can write the prediction formula $\mathrm{y}=-12,574+$ $0,895 x$. If there are students get a motivation score of 100 then the $y$ value of 76.926. Can also determine $\mathrm{T}_{\text {hitung }}$ of 2.28 is greater than

\begin{tabular}{|c|c|c|c|c|c|}
\hline \multirow[t]{2}{*}{ Model } & \multicolumn{2}{|c|}{$\begin{array}{l}\text { Unstandardi } \\
\text { ze d } \\
\text { Coefficients }\end{array}$} & $\begin{array}{l}\text { Standard ized } \\
\text { Coefficie } \\
n t s\end{array}$ & $\mathrm{~T}$ & Sig. \\
\hline & B & $\begin{array}{l}\text { Std. } \\
\text { Error }\end{array}$ & Beta & & \\
\hline \multirow{6}{*}{$\begin{array}{l}\text { (Constan } \\
\text { t) }\end{array}$} & - & 33.558 & & - & .714 \\
\hline & 1 & & & .37 & \\
\hline & 2. & & & & \\
\hline & 5 & & & & \\
\hline & 7 & & & 5 & \\
\hline & 4 & & & & \\
\hline \multirow[t]{3}{*}{ Motivasi } & .8 & .391 & .521 & 2.2 & .038 \\
\hline & 9 & & & & \\
\hline & 5 & & & & \\
\hline belajar & & & & 85 & \\
\hline (X) & & & & & \\
\hline
\end{tabular}

\section{Discussion}

Based on the motivation data obtained using the model TGT assisted by the YuGiOh card in this study, it showed that students who are in the very good category are $62.5 \%$ and good categories are $37.5 \%$. The high motivation will influence students' interest in learning about the classification of living things and things. Student interest in using the TGT can be seen at the tournament stage in conveying ideas. Lestari, Widiyatmoko, Alimah, \& Juliyani (2015) stated that competitive factors in the TGT model are needed in learning to influence student motivation. The tournament stage in the TGT syntax will make students more interested and motivated in learning. Slavin (2015) explained that the TGT model is a learning model that involves students in an academic game in the form of a quiz on the tournament table. At the tournament stage requires the responsibility of each individual in answering the question adding to the group score.

Nugraha (2018) Science learning is the process of finding a systematic problem to find out a material, mastering facts, concepts or principles. The science learning process 
emphasizes the experience process directly through the discovery process so that students gain a deeper understanding of a concept. Based on the results of direct interviews at MTs Baitul Amin Bali that student learning motivation is still relatively low. The low motivation of students in learning is due to several factors such as the lack of science learning media. Setyaningsih \& Dewi (2015) stated that varied learning media make the learning process atmosphere enjoyable and meaningful. Media learned that both need to be adjusted to the material and objectives to be achieved in order to avoid boredom in the learning process.

Motivation has a very important role in influencing the success of the learning process and the impact on the objectives to be achieved. Slameto (2010) states that motivation is very influential in student learning activities in achieving an achievement. There are three motivational functions, that is: (1) the appearance of actions or actions such as learning; (2) motivation is useful for determining the speed or slowness of an action; (3) motivation is useful for directing actions in achieving a desired goal. Motivation to learn that observed in the researchers 'based on the indicators of Uno (2008), that is: an indicator of students' motivation is the desire to succeed, the need for learning, their ideals of the future, the appreciation in the learning process, the activities of interest in learning, and the existence of a conducive environment. The following are descriptions of learning motivation indicators.

The first motivational indicator is the desire to succeed. The success of the first indicator can be known through understanding the material obtained while working on the discussion sheet and student worksheets that will affect student success in answering questions in the tournament. The application of model TGT assitance by $\mathrm{YuGiOh}$ card changes the way of learning that initially only listens and records to be actively involved in finding material. Based on the calculation of the application of model TGT assitance by YuGiOh card the average value of the first indicator of learning motivation showed a percentageof $81 \%$ whichiscategorizedas very high. Fathurrohman (2004) stated that students who have a high level of understanding and desire to learn will influence learning success. Goleman (2005) explained that motivation is a behavior that arises from a student's desire or need to learn. Students' desire in learning will influence the achievement of the learning process objectives.

The second motivation indicator is the need for learning. The need for learning is indicated by the absence of students playing alone or working on tasks other than the Science and answering each question at the tournament stage with the YuGiOh card. Student interest in learning will lead to the desire to know the material that has been or will be taught. Students' motivation in learning can affect the number of student attendance in the class. Based on the calculation of the model TGT assisted by the YuGiOh card the average value of the second indicator of learning motivation is categorized as very high with a percentage of $85 \%$. Aniswita \& Handayani (2017) stated that students who are motivated in doing something because of the needs to be achieved. Motivation will change students' behavior in order to be able to achieve maximum result learning. Sadirman (2006) stated that the requirement is an impulse that comes from within to carry out a job that needs to be done through the learning process. Awareness of the need for learning can be done by providing the motivation on students by providing guidance on activities so that the learning objectives be more easily achieved.

The third indicator of motivation is the existence of future aspirations. The success of the learning process can be seen from the positive behavior of students who are sustainable in the future. Learning by using the model TGT assisted YuGiOh card can influence students to have a sense of care for the surrounding environment. Based on the calculation of the average value of the third indicator learning motivation showed a percentage of $86 \%$ which is categorized as very high. Fauziah, Rosnaningsih, \& Azhar (2017) explained that students who understand the ideals or expectations will influence the spirit of learning. Students who have high motivation a reable to understand do realize 
the goals achieved in the future. Ardianto (2017) stated that the environment is a very good and real learning resource for students. Improving the sense of caring for the environment and strengthening the concepts that have been taught can be done by inviting students to get used to learning about the surrounding environment. Hakim \& Syofyan (2017) stated that science learning was presented by combining the concepts of physics, chemistry and biology that would make a direct experience and develop competencies in understanding the natural surroundings.

The fourth indicator of learning motivation is the appreciation in the learning process. The award obtained by students in the process of learning activities is to get good grades. The good grades obtained will make students become happy and motivated to answer each question, especially at the tournament stage. Students who get good grades will feel more excited in learning. Calculation of the average value of the fourth indicator of learning motivation for the model TGT assisted YuGiOh card is categorized as high with a percentage of $89 \%$. Djaali (2008) stated that appreciation is something that is given in the form of money or goods as a reward or service provided to students. Sadirman (2006) stated that teachers can influence motivation from within by applying various ways that come from outside such as giving rewards such as praise, grades or awards.

The fifth indicator is the existence of interesting activities in the learning process. The use of YuGiOh card media on living creature classification material will influence enthusiasm and attention using interesting learning media by giving students the task first through the discussion process. Based on the calculation of the average value of the fifth indicator learning motivation is categorized as very high with a percentage of $84 \%$. Sudarmin (2015) explained that there are several benefits of media in student learning processes such as growing student learning motivation, learning more easily understood by students, more varied learning and many students doing activities. Raisyifa \& Sutarni (2016) stated that varied learning strategies will influence students' learning motivation and make learning interesting. Conversely, if the lack of strategy in the learning process will make a lack of motivation in learning.

The sixth indicator is the existence of a conducive environment. An unpleasant atmosphere will cause crowds so students find it difficult to concentrate on understanding learning material. The use of the model TGT using YuGiOh card affects the enthusiasm and interest of students in the learning process which can be seen from the calculation of the average value of the sixth indicator of learning motivation showed a percentage of $89 \%$ which is categorized very high. Ardianto (2017) stated that conducive learning activities will make students follow the rules and rules that are applied so as to increase students' attention in the learning process. Putra (2013) stated that the atmosphere in learning also influences result of cognitive learning in learning activities. The atmosphere at the time of research is sometimes not conducive so some students who cannot concentrate in the learning process.

The model TGT assisted YuGiOh card provides a new atmosphere in the learning process so that it can increase motivation, student activity and increase concentration in learning. High motivation will provide stimulus to students in the learning process and create a pleasant atmosphere. Hakim \& Syofyan (2017) stated that the model TGT learning can influence students' motivation and attention in the learning process. The learning process becomes more interesting if there is motivation in the students themselves without any encouragement or coercion from other parties.

The model TGT learning assisted by the YuGiOh card in Figure 4.3 provides information on students' cognitive data. Data on students' result of cognitive learning from post-test results can be categorized very well by $6 \%$, both by $31 \%$, enough by $44 \%$ and less by $19 \%$. Result learning are students' abilities in the cognitive, affective and psychomotor domains. Result learning ability can be known from the learning process in working on a series of result learning tests (Afirin, 2012). Sutarto (2017) explained that cognitive or often called cognition is the ability to think and 
observe which results in someone getting the information needed to use knowledge. The main processes in cognitive include: interpreting, remembering, evaluating, inferring and grouping. Result cognitive learning on the model TGT learning assited by the YuGiOh card contain material and concepts based on Bloom's taxonomy consisting of 6 levels. Bloom (1956) stated that there are 6 criteria for the cognitive domain of Bloom's taxonomy, that is: (1) remembering, (2) understanding, (3)applying, (4) analyzing, (5) evaluating, and (6) creating. The following are each description of result cognitive learning indicators.

The first indicator is remembering. Students try to recall the material learned at home before doing the learning process. Remembrance indicators contained in learning about surrounding objects that are artificial by explaining the characteristics of living things around and grouping living things based on the classification principle. Gunawan \& Retno Palupi, (2016) explained that remembering is the ability of students to recount information or knowledge obtained by students in learning. Gunawan \& Retno Palupi (2016) stated at the level of remembering or remembering, where the ability of students to recall what was obtained in the form of information or simple knowledge. So the ability of students to remember is only memory data or information without any changes in manipulation.

The second indicator is understanding. Students need to build an understanding in understanding the material classification of living things and things. Students can understand each message or information when working on a discussion sheet or student worksheet. Students can also use the holding book to increase knowledge in order to better understand the material classification of living things. The model TGT learning assisted by the YuGiOh card contains an explanation of the surrounding objects that are scientific in nature, the characteristics of living things, grouping living things based on the principle of classification, and predicting the characteristics of plantae. Gunawan \& Retno Palupi (2016) explained that Understanding is a student's ability to understand a material that has been taught in the previous material.
Understanding is divided into three, that is: (1) translation is a way of understanding a material from the original statement, (2) interpretation is an explanation in the form of tables or diagrams, and (3) extrapolation is to expand known data to be applied to the surrounding conditions.

The third indicator is applying. Classical learning is usually the teacher only uses lecture methods that can make students feel bored. But the use of the model TGT learning assited by the $\mathrm{YuGiOh}$ card will make it easier for students to apply the method of grouping images of animals and plants around the school. Pictures of animals and plants deliberately spread by teachers who aim to be found and grouped according to the principle of classification. On the media the $\mathrm{YuGiOh}$ card contains the uses and classifiers of objects, predicts the characteristics of living things, uses a microscope, investigates the characteristics of protists, animalia and fungi. According to Gunawan \& Retno Palupi (2016) apply is the ability of students to do something and apply concepts to certain situations. Fatimah (2017) stated that learning using media can be used to influence students' interests and motivation. High motivation will make the atmosphere fun so that the desired result learning are realized.

The fourth indicator is analyzing. Students in the learning process are invited to analyze the parts of the microscope and identify living things in the form of macros. The analyzing domain contained in the YuGiOh card is one way to analyze living things and objects, diagnose the characteristics of living things, and analyze the characteristics of monera, animalia, fungi. Fauzi (2017) explained that analysis is the ability of students to identify parts, link with various experience experiences and recognize each part. Result learning domain analysis affect students' ability to understand each part of the material as well as the grouping structure.

The fifth indicator is evaluating. Students at the tournament or game stage are asked to evaluate the questions using the YuGiOh card. The media of the YuGiOh card contains discussions such as summing things that are simple and complex, predicting living things and objects, concluding the principle of 
classification. Sudarmin (2015) stated that games or games are activities that consist of solving problems to face game challenges by following the rules. Problems and rules in a game are made into a storyline. According to Fauzi (2017) assessment or evaluation is the level of students' ability in taking consideration of situations, values or ideas. Like, if students are given a choice in facing how many choices to answer the question correctly. According to Afirin (2012) the usefulness in evaluating the correct answers in learning will make students aware of what to do when understanding the material. Each question given will make students understand the meaning of the question in order to be able to solve and account for each answer.

The sixth indicator is making or creating. Students are required to conclude the results of the worksheets of students about the different characteristics of living things and objects that are around the school. The YuGiOh card also contains characteristics of surrounding objects that are natural, characterize living things based on classification, and estimate the use of the key to determination. Gunawan \& Retno Palupi (2016) stated that creating cognitive category indicators is the ability of students to integrate an element into a complete and coherent form in forming a truth. Gunawan \& Retno Palupi (2016) explained that at the level of creating or creating that refers to the ability of students to integrate and develop various materials obtained.

The influence of motivation on result cognitive learning using the model TGT assisted by the YuGiOh card in a simple linear regression test (Table 4.2) obtained a constant value (a) of -12.574 and a value of (b) of 0.895 . Simple linear regression equation $y=-$ $12,574+0,895 \mathrm{x}$, with $(\mathrm{y})=$ result cognitive learning (dependent variable) and $(\mathrm{x})=$ learning motivation (independent variable). Proof of hypothesis in the study can be seen from the value of $t_{\text {count }}$ and the value of Sig. In Table 4.2, the value of $t_{\text {count }}(2.28)$ is greater than $\mathrm{t}$ table (2.14). In addition, decision making can also be seen in Table 4.2using the Sig. 0.038 which is smaller than $\alpha(0.05)$ which indicates that there is a significant influence.
Based on the calculation results from $t_{\text {hitung }}$ and Sig concluded Ho is rejected and Ha is accepted which means that there is a positive and significant influence between learning motivation and result cognitive learning using the model TGT assisted by the YuGiOh card. The results of this study are supported by previous research Sadirman (2006) which showed that learning motivation is very influential on result cognitive learning of science learning that is equal to $48.1 \%$ with an average value of 87.46 and result cognitive learning with an average value of 88, 46. Supported by research by Damopolii, Nunaki, \& Supriyadi (2018) and Sunarti \& Susanti (2016) which explained that motivation has a positive correlation to result learning.

Table 4.1 showed that learning motivation in science learning with the TGT model assisted YuGiOh card influences result cognitive learning by $27.2 \%$. The influence is not only influenced by motivation but is influenced by the use of learning videos and student worksheets. Febriani (2017) stated that video use in learning can lead to curiosity about the material being taught. Curiosity that comes with the help of video learning will lead to high learning motivation. Curiosity arises from the senses used in paying attention to the video including the visual senses and the sense of hearing. The more use of the senses in learning will influence students in understanding various materials taught. Ulfiatun, Dewi, \& Khusniati (2017) explained that the use of student worksheets can increase student activity and motivation in the learning process. Based on the results of the calculation of the use of student worksheets that meet the standards of class completeness reaches $70 \%$. Ulfiatun, Dewi, \& Khusniati (2017) stated that student worksheets are teaching materials needed by students in solving learning problems. Student worksheets are usually in the form of instructions, rules and assignments. Student worksheets function to encourage students to study independently.

Based on the calculation of the study that result cognitive learning are influenced by other factors by $72.8 \%$. Djamarah (2011) stated that several factors that influence result cognitive learning are not only motivation to learn but there is readiness in learning, social 
support and learning facilities. During the first meeting until the last meeting, some students did not bring handbooks and stationery so that activities became hampered and showed less readiness in learning. Putri (2015) stated that student learning readiness is a condition in students who are ready to conduct learning process activities. Readiness of students in learning can also be interpreted as readiness in the physical, psychological and material sense. Psychic readiness for example concentration and motivation to learn. While material readiness for example is the existence of books, study notes, modules and student worksheets used in learning. Djaali (2007) stated that readiness or readiness is a condition that allows students to learn. Readiness of students in learning, including: a) studying past material; b) complete training; c) maintain physical health and fitness; d) looking for materials to add information; and e) preparing learning equipment.

The lack of interaction between students has an impact on the collaboration in completing the discussion worksheets. The purpose of the discussion aims to increase cooperation between students. Wulanda, Putri, \& Ridha (2017) stated that social support is a form of attention and assistance provided by other individuals. Social support arises from an event or event that is seen as having a problem to solve together. Efendi, Suhartadi, \& Yoto (2016) stated that there is a very significant positive relationship between social support and academic achievement. The higher social support between individuals, the result learning will make result learning high. Conversely, the lower the social support, the lower the learning outcomes will be.

Other factors that influence result learning are lack of facilities and infrastructure owned by students and schools. Supanti (2017) explained that the completeness of equipment in learning that is owned by students and schools will affect student result learning. Lack of learning equipment can have a negative impact on students as it is difficult to understand the material being taught so that the goals to be achieved become less optimal. Learning facilities can be said to be complete if students have the facilities and infrastructure needed in the learning process, including: comfortable classrooms, writing desks, chairs, books and stationery. Monika \& Adman (2017) explained that facilities in learning will make students more enthusiastic, motivated, not easily bored, helping students and teachers in carrying out the learning process. So that it requires completeness directly or indirectly with students in supporting the smoothness and success of the learning process such as learning media, learning tools, school supplies, and others.

The results showed that learning motivation had a positive effect on result cognitive learning in science learning using the model TGT assisted by the YuGiOh card.

Teachers or prospective researchers who are interested in conducting research using the model TGT assisted by the YuGiOh card must be careful when the learning process takes place. Keeping the classroom condition conducive so students are easier to learn using the TGT model with the help of the YuGiOh card.

\section{CONCLUSIONS AND SUGGESTIONS}

The results showed that the motivation to learn positive effect on result cognitive learning in science learning using the model TGT assisted card YuGiOh. The percentage of influence of motivation on cognitive learning result using TGT model with YuGiOh card is $27,2 \%$ while the rest equal to $72,8 \%$ influenced by other factors.

Teachers are expected to consider the allocation of time needed in learning, considering the cooperative learning model activity is closely related to the learning time used.

\section{REFERENCES}

Afirin, Z. (2012). Evaluasi Pembelajaran Prinsip, Teknik, Prosedur. Bandung: PT Remaja Rosdakarya.

Angreni, S., \& Sari, R. T. (2017). Analisis Ketersediaan, Kondisi, dan Kendala dalam Penggunaan Media Komponen Instrumen Terpadu IPA di Sekolah Dasar. Jurnal Bioedukatika, 5(2), 92-96. https://doi.org/10.26555/bioedukatika.v5i 2.7689

Aniswita, \& Handayani. (2017). Kemampuan 
Komunikasi Matematis dengan Accelerated Learning. Math Educa Journal, 1(2), 142-155. Retrieved from https://ejournal.uinib.ac.id/jurnal/index.ph $\mathrm{p} / \mathrm{matheduca/article/view/22/22}$

Ardianto, A. Y. I. (2017). Hubungan Manajemen Kelas Dengan Hasil Belajar Siswa di SDN Gugus Krisna Kecamatan Semarang Barat Kota Semarang. Universitas Negeri Semarang. Retrieved from

https://lib.unnes.ac.id/31208/1/140141235 5.pdf

Bloom, B. (1956). Taxonomy of Educational Objectives: The Classification of Educational Goals, Handbook I Cognitive Domain. New York: Longmans, Green and Co.

Damopolii, I., Nunaki, J. H., \& Supriyadi, G. (2018). Effect of Problem Solving Learning Model on Students Achievement. Journal of Education Research and Evaluation, 2(1), 1-9.

Djaali. (2008). Psikologi Pendidikan. Jakarta: Bumi Aksara.

Djamarah, S. B. (2011). Psikologi Belajar. Jakarta: Rineka Cipta.

Efendi, S. H., Suhartadi, S., \& Yoto. (2016). Hubungan antara Berfikir Kreatif dan Dukungan Sosial dengan Prestasi Belajar Mahasiswa Jurusan Teknis Mesin Fakultas Teknik Universitas Negeri Malang. Jurnal Pendidikan Profesional, 5(3), 76-90. Retrieved from journal.stainkudus.ac.id > index.php > jmtk $>$ article $>$ view $\% 0 \mathrm{~A} \% 0 \mathrm{~A}$

Fadilatullailiyah. (2015). Penggunaan Modul Berbasis Kontekstual Untuk Meningkatkan Hasil Belajar Siswa Pada Pokok Bahasan Struktur da Fungsi Sistem Peredaran Darah di Kelas XI MAN Babakan Ciwaringin Ciberon. Institut Agama Islam Negeri Syekh Nurjati Cirebon. Retrieved from http://eprints.iainsurakarta.ac.id/1075/1/FULL TEKS.pdf

Fathurrohman, M. T. (2004). Pengaruh Perhatian Orang Tua Terhadap Prestasi Belajar Siswa Kelas V. Jurnal Pendidikan Guru Sekolah Dasar, 6(10), 975-982. Retrieved from journal.student.uny.ac.id > ojs > index.php > pgsd > article > download
Fatimah, I. D. (2017). Penerapan Model Pembelajaran Make A Match dengan Media Kartu Bergambar Untuk Meningkatkan Motivasi dan Hasil Belajar Siswa. Ilmu Pendidikan, 2(1), 28-37.

Fauzi, A. (2017). Daya Serap Siswa Terhadap Pembelajaran Taksonomi Pendidikan Agama Islam. Jurnal Pusaka, 1(8), 5067.

Fauziah, A., Rosnaningsih, A., \& Azhar, S. (2017). Hubungan antara Motivasi Belajar Dengan Minat Belajar Siswa Kelas IV SDN Poris Gaga 05 Kota Tanggerang. Jurnal Pendidikan Sekolah Dasar, 4(1). Retrieved from journal.uad.ac.id , index.php > JPSD , article , download\%0A\%0A

Febriani, C. (2017). Pengaruh Media Video terhadap Motivasi Belajar dan Hasil Belajar Kognitif Pembelajaran IPA Kelas V Sekolah Dasar. Corry Febriani, 5(1), 11-21.

Goleman, D. (2005). Kecerdasan Emosi Untuk Mencapai Puncak Prestasi. Jakarta: PT Gramedia Pustaka Utama.

Gunawan, I., \& Retno Palupi, A. (2016). Taksonomi Bloom-Revisi Ranah Kognitif: Kerangka Landasan untuk Pembelajaran, Pengajaran, dan Penilaian. Premiere Educandum. Jurnal Pendidikan Dasar Dan Pembelajaran, 2(02), 98-117. https://doi.org/10.25273/pe.v2i02.50

Hakim, S. A., \& Syofyan, H. (2017). Pengaruh Model Pembelajaran Kooperatif Tipe Teams Games Tournament (TGT) Terhadap Motivasi Belajar IPA di Kelas IV SDN Kelapa Dua 06 Pagi Jakarta Barat. International Journal of Elementary Education, 1(4), 249-263.

Hutauruk, P., \& Simbolon, R. (2018). Meningkatkan Hasil Belajar Siswa dengan Alat Peraga Pada Mata Pelajaran IPA KElas IV SDN Nomor 14 Simbolon Purba. School Education Journal, 8(2), 121-129. Retrieved from https://jurnal.unimed.ac.id/2012/index.ph p/school/article/viewFile/9770/9295

Lestari, A., Widiyatmoko, A., Alimah, S., \& Juliyani, I. (2015). Sounds Learning Using Teams Games Tournament with Flash Card As Media at The 13Th Junior High School Of Magelang. Jurnal 
Pendidikan IPA Indonesia, 4(2), 177-184. https://doi.org/10.15294/jpii.v4i2.4188

Monika, \& Adman. (2017). Peran Efikasi Diri dan Motivasi Belajar dalam Meningkatkan Hasil Belajar Siswa Sekolah Menengah Kejuruan. Jural Pendidikan Managemen Perkantoran, 2(2), 109-116.

Nugraha, W. S. (2018). Penguasaan Kemampuan Berpikir Kritis dan Penguasaan Konsep IPA Siswa SD Dengan Menggunakan Model Problem Basef Learning, 10(2), 115-127. Retrieved from ejournal.upi.edu , index.php > eduhumaniora > article > download > pdf $\% 0 \mathrm{~A} \% 0 \mathrm{~A}$

Putra, S. R. (2013). Desain Belajar Mengajar Kreatif Berbasis Sains. Jogjakarta: Diva Press.

Putri, D. T. N. (2015). Pengaruh Minat Dan Motivasi Terhadap Hasil Belajar Pada Mata Pelajaran Pengantar Administrasi Perkantoran. Jurnal Pendidikan Bisnis Dan Manajemen, 1(2), 118-124.

Raisyifa, D. N., \& Sutarni, N. (2016). Pengaruh Kinerja Mengajar Guru Terhadap Motivasi Belajar Siswa (Effect of the teaching performance of teachers on students, motivation). Jurnal Pendidikan Manajemen Perkantoran, 1(1), 90-98. Retrieved from ejournal.upi.edu > index.php > jpmanper > article $>$ download $\% 0 \mathrm{~A} \% 0 \mathrm{~A}$

Rifa'i, \& Ani. (2012). Psikologi Pendidikan. Semarang: UNNES Press

Roisa, A., \& Liana, C. (2014). Pengembangan Media Permainan Kartu Yu-Gi-Oh untuk Meningkatkan Kualitas Pembelajaran Sejarah pada Materi Indonesia Masa Islam di Kelas X IPA SMA. E-Journal Pendidikan Sejarah, 2(3). Retrieved from https://jurnalmahasiswa.unesa.ac.id/index. php/avatara/article/view/8335/8495

Sadirman. (2006). Interaksi dan Motivasi Belajar Mengajar. Jakarta: Raja Grafindo Persada.

Setyaningsih, M. D., \& Dewi, N. R. (2015). Pengembangan Media Papan Permainan Berbasis Scince- Edutainment Tema Makanan untuk Siswa Kelas VIII. Unnes Science Education Journal, 4(3), 965972.
Slameto. (2010). Belajar dan Faktor-Faktor yang Mempengaruhinya. Jakarta: Rineka Cipta.

Slavin, R. E. (2015). Cooperative Learning. Bandung: Nusa Media.

Sudarmin. (2015). Model Pembelajaran Inovatif Kreatif. Semarang: UNNES Press.

Sunarti, I., \& Susanti. (2016). Pengaruh Kompetensi Pofesional Guru Terhadap Motivasi Belajar Siswa Serta Implikasinya Terhadap Hasil Belajar Siswa. Jurnal Equilibrium, 14, 22-37.

Supanti, D. (2017). Hubungan Antara Persepsi Siswa Tentang Perhatian Orang Tua Terhadap Hasil Belajar Mata Pelajaran Aqidah Akhlak Kelas VIII di MTS Negeri Karangmojo Tasikmadu Karanganyar Tahun 2016/2017. Institut Agama Islam Negeri Surakarta. Retrieved from http://eprints.iainsurakarta.ac.id/1075/1/FULL TEKS.pdf

Surahmadi, B. (2016). Penerapan Teknik Permainan Kartu Pintar Untuk Meningkatkan Motivasi Belajar dan Hasil Belajar IPA. Jurnal Pendidikan Fisika, IV(1), 17-25.

Sutarto. (2017). Teori Kognitif dan Implikasinya dalam Pembelajaran. Islamic Counsseling, 1(02), 1-26.

Ulfiatun, Dewi, N. R., \& Khusniati, M. (2017). Efektivitas Penggunaan LKS IPA Terpadu Bervisi Salingtemas (SainsLingkungan- Teknologi-Masyarakat) Berbasis Science Entrepreneurship terhadap Keterampilan Komunikasi Ilmiah dan Minat Berwirausaha Siswa. Pancasakti Science Education Journal, 2(2), 74-88.

Umar, N. H. M., Parmin, \& Wusqo, ndah U. (2016). Pengaruh Media Kartu Pintar Tumbuhan Berbasis Science Edutainment terhadap Minat Belajar dan Pemahaman Konsep Siswa Tema Gerak Tumbuhan. Unnes Science Education Journal, 5(2), 1288-1297.

Uno, H. B. (2008). Teori Motivasi dan Pengukurannya: Analisis di Bidang Pendidikan. Jakarta: Bumi Aksara.

Wijayanto, E., \& Istianah, F. (2017). Pengaruh Penggunaan Media Game Edukasi Terhadap Hasil Belajar IPA Siswa Kelas 
IV SDN Kajartengguli Prambon Sidoarjo. Jurnal Pendidikan Guru Sekolah Dasar, 05(03).

Wulanda, M., Putri, D., \& Ridha, M. (2017). Hubungan ntara Dukungan Sosial Orangtua dengan Kepercayaan Diri Siswa di SMP Negeri 22 Padang. Jurnal
Penelitian Guru Indonesia, 2(1), 19-23. Retrieved from http://jurnal.iicet.org/index.php/jpgi/articl e/view/215 